\title{
Social Distance Into Factual Information Distance about COVID-19 in Indonesia Whatsapp Groups
}

\author{
Muhammad Taufiq Syam ${ }^{1}$, Zulkifli Makmur², Askar Nur ${ }^{3}$ \\ ${ }^{1}$ Communication And Islamic Broadcasting Study Program, Faculty of Ushuluddin, Adab and Dakwah \\ State Islamic Institute Parepare \\ Jl. Amal Bhakti No.8, Bukit Harapan, Kec. Soreang, Kota Pare-Pare, Sulawesi Selatan 91131, Indonesia \\ ${ }^{2}$ Dakwah Management Study Program of Islamic College Darul Dakwah Wal Irsyad Makassar \\ Jl. Sultan Alauddin 3 No.8, Mangasa, Kec. Tamalate, Kota Makassar, Sulawesi Selatan 90221, Indonesia \\ ${ }^{3}$ English and Literature Department of Adab and Humanities Faculty, Alauddin State Islamic University \\ Jl. Sultan Alauddin No.63, Romangpolong, Kec. Somba Opu, Kabupaten Gowa, Sulawesi Selatan 92113, Indonesia \\ Email: muhtaufiqsyam@iainpare.ac.id ${ }^{1 *}$; zulkifli.makmur@mail.ugm.ac.id ${ }^{2 ;}$ askarr.nur@gmail.com ${ }^{3}$ \\ *Corresponding author
}

\begin{abstract}
WhatsApp has become a forum for communication and information related to the COVID-19 pandemic, so there are messages that ignore the identification and validation of news facts. This creates an information gap on WhatsApp. This study aims to analyze the form of information gaps related to information on the COVID-19 pandemic in Indonesia shared by WhatsApp group users. This research uses quantitative research methods, with data collection techniques through documentation of text messages and pictures, as well as the results of a survey conducted on WhatsApp group users. The results of this research indicate that the information gap in reporting the COVID-19 pandemic occurs due to information gaps in the form of uncertainty, strong beliefs and opportunities to choose information and decisions to choose information values. The substance of this research contributes in the form of new policy recommendations in assessing information gaps in social media by validating the truth of the facts in each message received and shared to another users. Keywords: COVID-19; Information Gaps; WhatsApp Group in Indonesia
\end{abstract}

\begin{abstract}
Abstrak
WhatsApp menjadi wadah komunikasi dan informasi terkait pandemi COVID-19, sehingga ada pesan yang mengabaikan proses identifikasi dan validasi fakta berita. Hal tersebut menimbulkan kesenjangan informasi di WhatsApp. Penelitian ini bertujuan untuk menganalisis bentuk kesenjangan informasi terkait informasi pandemi COVID-19 di Indonesia yang dibagikan oleh pengguna grup WhatsApp. Penelitian ini menggunakan metode penelitian kuantitatif, dengan teknik pengumpulan data melalui dokumentasi pesan teks dan gambar, serta hasil survei yang dilakukan terhadap pengguna grup WhatsApp. Hasil penelitian ini menunjukkan bahwa kesenjangan informasi dalam pemberitaan pandemi COVID-19 terjadi akibat kesenjangan informasi berupa ketidakpastian, keyakinan yang kuat dan peluang untuk memilih informasi serta keputusan untuk memilih nilai infomasi. Subtansi penelitian ini memberikan kontribusi berupa rekomendasi kebijakan baru dalam mengkaji kesenjangan informasi di media sosial dengan cara memvalidasi kebeneran fakta pada setiap pesan yang diterima dan dibagikan kepada pengguna lainnya. Kata kunci: COVID-19; Kesenjangan Informasi; Group WhatsApp di Indonesia
\end{abstract}

\section{Introduction}

In 2020, the world is undergoing a severe test with the outbreak of an acute pneumonia called coronavirus disease 2019 (COVID-19). The pandemic of COVID-19 can cause respiratory organ malfunction that leads to death with the initial symptoms of the patient in the form of fever, sore throat, fatigue to shortness of breath (Verity et al., 2020) assuming a constant attack rate by age and adjusting for the demography of the population, and age and locationbased under ascertainment. We additionally estimated the CFR from individual linelist data on 1,334 cases identified outside mainland China. We used data on the PCR prevalence in international residents repatriated from China at the end of January 2020 to obtain age-stratified estimates of the infection fatality ratio (IFR). 
The first case of the COVID-19 pandemic occurred in Wuhan City, Hubei Province, China, which was began in December 2019 (Cheng et al., 2020). Data obtained from the World Health Organization (WHO) website shew that most cases of the COVID-19 pandemic sufferers were actually in Hubei Province, from 258 cases on January 21, 2020 jumping to 62,031 cases on February 20, 2020 (WHO Coronavirus Disease COVID-19, 2020).

Beginning investigation, it was shownthis virus was the result of interactions between humans and bat animals sold in the animal market of Wuhan City. These results are based on the findings of genomic investigation and the presence of several bats and live animals on the animal market, and believed to have carried the SARS$\mathrm{CoV}-2$ virus (the initial code for COVID-19). This virus is continuously contaminated with other merchandise and also with humans in the market and surrounding areas (Lai, Shih, Ko, Tang, \& Hsueh, 2020). This market subsequently became the initial epicenter of the spread of the COVID-19 virus to humans and continued to experience an exponential increase in almost all regions of China and in other countries brought by foreign tourists who have visited the place.

In Indonesia, the COVID-19 case was first confirmed on March 2, 2020, where there were two sufferers in a family of 64 years old mother and 31-year-old daughter in Depok, West Java. The cause of their lunge, because it previously had made contact with foreign citizens who came to Indonesia who had previously contracted the virus. Confirmation was delivered directly by President Joko Widodo accompanied by Minister of Health, Terawan Agus Putranto in a press conference held on March 3, 2020 (Rochmyaningsih, 2020; Yunita, 2020). During the press conference, the President of Indonesia and Minister of Health conveyed the case had been handled optimally by the medical team.

On the other hand, the outbreak impact of the COVID-19 in Indonesia has massively caused an effect ofmoral panic in society. Moral panic means the condition that arises due to the emergence of a situation, event or groups of people who are considered as a threat to the values and interests of society (Cohen, 2011). This moral panic is generally caused by the news that is distributed through communication occurred in public space. One of them is through public space based on digital social media, specifically on WhatsApp.

Previously, there had been research on Covid 19 news on social media, research entitled The Covid-19 Social Media Infodemic (Cinelli et al., 2020). The research identified information spreading from dubious sources, found the volume of information contained on the Twitter social media platform, Instagram, YouTube, Reddit, and Gab. This research states that the information from untrustworthy and questionable sources does not show a different pattern of distribution. There is also a study entitled The influence of social media in the COVID-19 Pandemic (González-Padilla \& Tortolero-Blanco, 2020). This research concluded the most relevant information about the effects, advantages and disadvantages of using social networks during the COVID-19 pandemic. The research entitled Fake News and Covid-19: Modeling The Predictors of Fake News Sharing Among Social Media Users (Apuke \& Omar, 2020), about the phenomenon of spreading fake news on social media related to Covid-19 in Nigeria caused by user motivation social media to share information, socialize, search for information, and free time to spread the false information. Lastly, The research entitled COVID-19: Threat and Fear in Indonesia (Abdullah, 2020) that discuss about four different types of psychological trauma were increasingly observed, based on digital communication with people affected and reports from the news and social media. These 4 types of psychological trauma were social withdrawal, hysteria, individual violence, and collective violence.

In Indonesia, early news regarding the spread of COVID-19 on social media was mostly shared on the WhatsApp group. News that is shared on WhatsApp, does not go through a filtering process regarding the truth of facts. The high volume of information on the WhatsApp platform affects the level of public trust in COVID-19 news, resulting in information gaps between users. 


\section{Digital Social Media}

Social media is online media which makes it easy for the user to participate, share, and socialize with their community. It has content, such as blog, social network, Wikipedia and the virtual world (Mahmuddin \& Halik, 2019). Social media also facilitates its user to communicate and interact with one another.

Digital social media is a collection of internetbased applications which are based on ideology and Web 2.0 technology to enable the creation and exchange of content by the user (Kaplan \& Mazurek, 2018; Anwar, 2017). The existence of digital social media currently has an important role in the social system in society. Social media integrated with the internet network has provided an opportunity for anyone to be directly involved in the process of distributing messages to the public, either in the position as a communicator or in a position as a communicant. This proves a conclusion that on digital social media, everyone will have a dual role, namely acting as a subject and also being the object of the message.

Digital social media consists of three main components, namely information infrastructure and tools used to produce and distribute media content, media content which consists of personal messages, news, ideas, and cultural products in the form of digital, and finally production and consumption of media content in digital form by individuals and organizations or groups (Rahadi, 2017). These components prove that as a communication infrastructure, social media allows mass production and consumption of news that can be carried out continuously both on a personal scale and on a wider scale in society.

Social media not only changes the way to deliver information but also the way of people to consume the information (Juditha, 2018). The opportunity provided by social media in the form of full equal freedom to every user to disseminate information without going through the process of filtering the correct news and fake news, encouraging reporting of information on social media.

\section{Information Gaps}

The information gap is described as informationor knowledge gap received by the public regarding a media coverage (Bungin \& Burhan, 2009). Information gaps can occur within a group if there are differences in information received by individual and there are different points of view in interpreting information.

Many things can cause information gaps, but in this study, the causes of information gaps are concluded in three ways, namely information gap of uncertainty, robustness and opportunity and decision of information value (Ben-Haim, 2004).

The first cause of information gaps is due to the information gap of uncertainty. This form of inequality occurs because of the lack of individual knowledge related to the truth of fact from information which furtherly impacts on the emergence of uncertainty related to the truth validation received. This information gap is formulated in a variable.

The information or news can be symbolized using variables (f), for the level of knowledge related to facts symbolized using variables (fe), and for the emergence possibility of varying perceptions using variables $(\alpha)$. If this formula is then applied in the form of information gaps, the result can be obtained that the greater value of fe, the greaterlevel of truth validation of a fact. Conversely, the greatervalue of $\alpha$, the greaterchance for information gaps occurred (Ben-Haim, 2004).

The second cause of information gap is due to a strong belief and the availability of opportunities to choose information (robustness and opportunity). The cause ofinformation gap comes from how much a person's tendency to establish confidence in a message which is then realized when choosing information to be disseminated. There are additional measurement scales in this form.

The strong belief is symbolized using variables (q) and for opportunity to choose information using variables (r). So when the valueqin $\mathrm{f}$ is more dominant, then the possibility of valuer will be smaller or with formulation. Conversely, when the value $\mathrm{q}$ in $\mathrm{f}$ is smaller, 


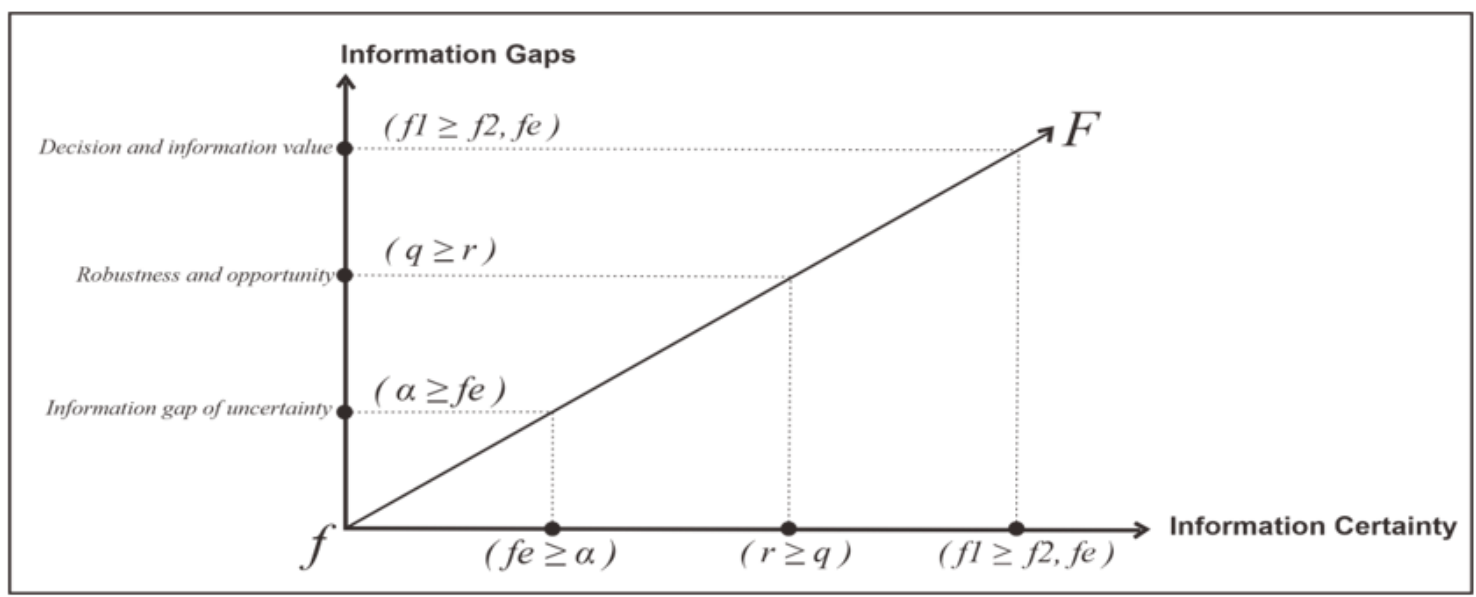

Figure 1. Information Gaps Scale

Soure: Ben-Haim (2004)

then the possibility ofvaluer will be even greater. From this formulation result, it can be illustrated thatthe stronger one's belief toward the truth of the message fact, the less chance of choosing alternative information, while the smaller one's belief toward the truth offact, the greateropportunity to choose other alternative information which is considered important to be conveyed to others (Ben-Haim, 2004).

The third cause of information gap arises from the decision to choose based on interest and information value (decision of information value). The cause of this information gap is divided into two things. First, the decision to choose which tends to make choice based on information interest. Second, the decision to choose a message is based on the aspect of evaluating information in the form of personal identification to distinguish between true and false news. To formulate the form, each message is given a symbol variable, f1, f2, f3, etc.

In the first scheme, for example when there is interest that information f1 is more interesting if it is compared with information $\mathrm{f} 2$ or $\mathrm{f3}$, it will be decided to selectinformation f1. Furthermore, in the second scheme, when the information valuefl is more inclined to facts which are actually compared with the information valuef 2 or $\mathrm{f} 3$, then the choice will fall on information f1 (Ben-Haim, 2004). The decision and judgment will give different result because there are variations in different interest and judgment in each individual. To understand these three forms of information gaps, the researcher will describe the formula on Figure 1.

After seeing the description and scale of the information gap formulation on Figure 1, it can be assumed that this is the case for almost all digital social media today. The similarity can be found of spreading messages through on WhatsApp.

\section{WhatsApp}

WhatsApp is digital social media application platform and generally enabled through smart phone and computer device. This application provides services for sending messages in the form of text, documents, images, videos and voice messages by using the mobile phone number from the user as a condition for using the service (Astarilla \& Warman, 2017). In addition to messaging services between individual, WhatsApp also provides communication services between groups via groups.

On social media, especially WhatsApp, information gaps are often found when someone shares information in a friend group. The information is generally sourced from other digital media, such as Facebook, Twitter, Instagram, YouTube or online media. When a message has been shared with the group all members can access it. Any information can be shared in the WhatsApp group without going through a filtering 


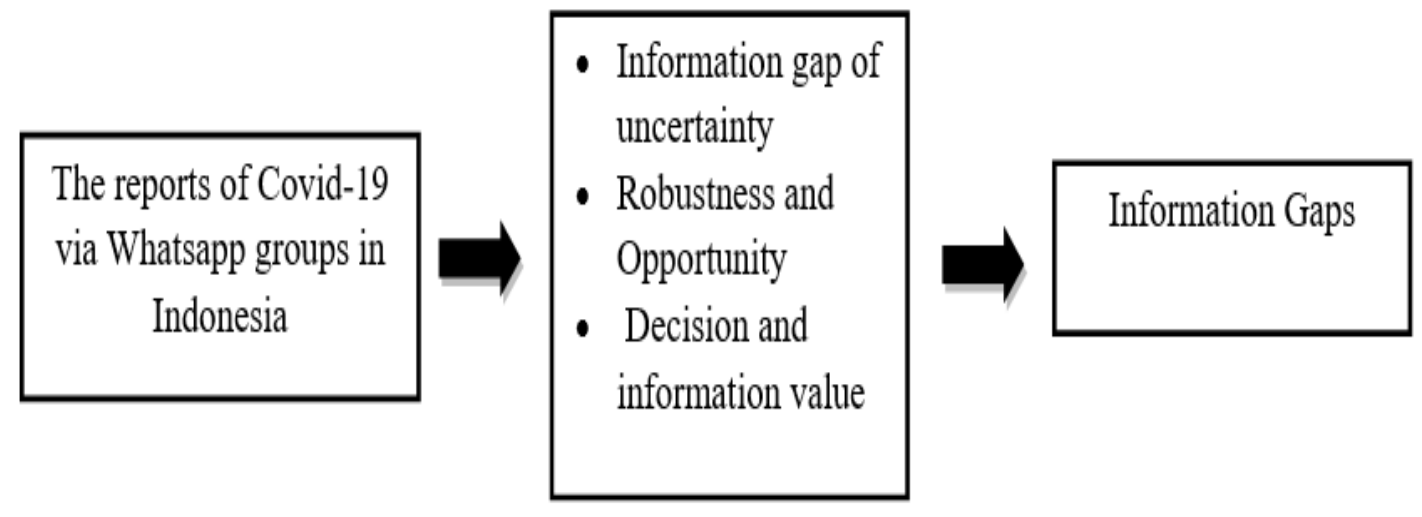

Figure 2: The Scheme of Information Gaps Related COVID-19 Virus Reports via Whatsapp Groups Source: Processed by Researchers (2020)

process that aims to identify and distinguish between true news and fake news (Juditha, 2018).

During the early days of the COVID-19 pandemic case in Indonesia, messages shared in WhatsApp groups aimed to provide answers to other users regarding developments in the COVID-19 pandemic case. However, the reality actually creates an information gap from WhatsApp group users when evidence is found that the messages that are shared are mostly not validated, the evidence contradicts one news with another based on the most dominant news opportunity needed, and affects public trust to belief an information.

Therefore, this research aims to prove that there has been information gaps regarding the reporting of COVID-19 pandemic case in Indonesia particularly early news on social media that refer to messages shared by WhatsApp group users referring to the cause analysis of Ben-Haim's information gap. The framework for solving the problem will be illustrated in Figure 2.

This chart shows that the unsubstantiated news related to the COVID-19 case in Indonesia spreads among users of the WhatssApp service group. It is described in three forms of information gaps which contributed to receive or reject information.

Based on the explanation, this research attempts to analyze the form of information gaps related to the information of COVID-19 pandemic in Indonesia, which was shared by WhatsApp group user.

\section{Research Methods}

This research uses a quantitative method, where the researcher acts as the key instrument of Investigation. The subjects of this research are the users of WhastsApp group in Indonesia and the objects of this research are messages that convey information related to the development of COVID-19 case that occurred in Indonesia during March 2020 which was distributed through WhatsApp groups. The selection period is based on the beginning of the active spread of COVID-19 in Indonesia in one month. This study uses data collection technique of the messages screenshot that are shared through in fifteen WhatsApp groups to obtain primary data sources.

Besides that, this research also uses the secondary data obtained from the results of the survey committed to the WhatsApp group users who received information related to COVID-19 in Indonesia. The analysis is conducted by first grouping messages based on the news related to the cause of the pandemic emergence, solutions and efforts to prevent the spread of impact that will be caused by the pandemic.

The research analysis technique uses the analysis of the Ben-Haim information gap consisting, such as information gaps cause the fact gap from the news that shared on the WhatsApp group, strong decision to choose and opportunity to choose information from the one of the news that had been obtained in 


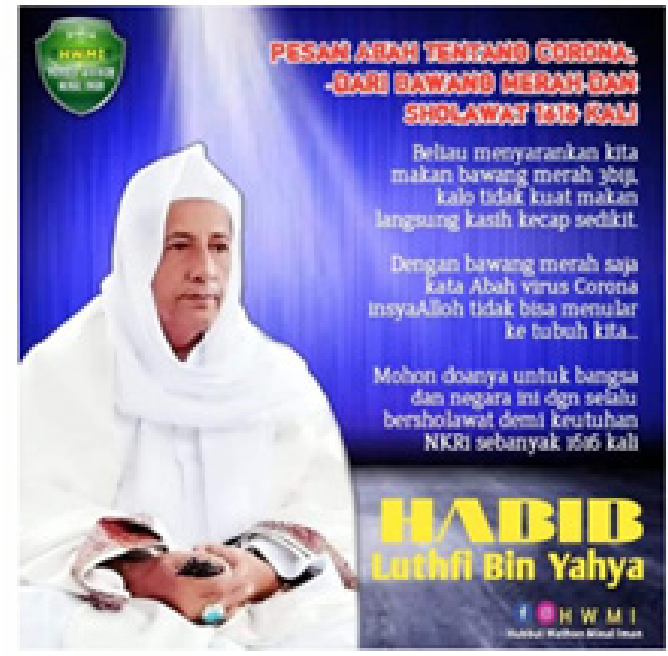

Figure 3: The onion can prevent COVID-19 virus Source: WhatsApp Group (2020)

the group and the value of information and the interest to several information and decision to chose the information value based on the level of trust and validation of the news fact.

\section{Results of Research and Discussion}

Until the end of March 2020, since the spread of COVID-19, the total number of sufferers in this outbreak has reached 789,218 spread in 200 countries, with a total of 38,090 fatalities and 16,441 people who have been declared cured (Worldometer, 2020).

Whereas in Indonesia itself, since COVID-19 case was first confirmed on March 2, 2020 until March 31, 2020, there has been an exponential increase in cases. Data from COVID-19 cases in Indonesia, already in 1,528 cases as of March 31,2020 , with details of 1,311 active cases, 136 patients died and 81 patients recovered, respectively. The following chart will show an increase in cases of patients from March 2, 2020 - March 31, 2020 (Update Covid-19, 2020).

Although official confirmation by the government about the discovery of the first COVID-19 case in Indonesia was only announced on March 03, but a few days earlier a chain message had circulated in several WhatsApp groups informing that in some areas cases COVID-19 spread case had been found by people brought from the area indicated as the epicenter of the epidemic.

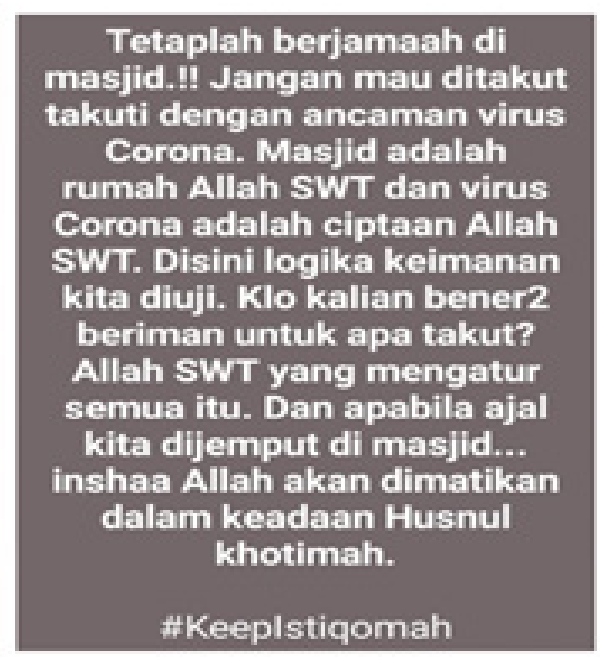

Figure 4: COVID-19 as the God's destiny Source: WhatsApp (2020)

\section{Information Gap of Uncertainty}

The desire to get a public trust, even with limited knowledge of the information shared, is sometimes committed only to cover the lack of knowledge related to the truth of information. Some information was shared by using a label such as putting the name of a public figure, thescientist or institution trusted by the public.

The purpose of the labeling action on a message is carried out, one of which is to show the users of the WhatsApp group that the truth of information is valid and there is no need to cross-check the correctness of the information. Some examples of messages that pass a form of labeling can be seen in the Figure 3.

In figure 3 share the information related to things that can prevent transmission of COVID-19 by including the name of a public figure to build public trust through information that contains the level of source credibility. However, this message did not inform the results of further research and there was no immediate confirmation from the people whose names were included in the message, so that in the end, The Ministry of Communication and Information Technology of Indonesia (Kemenkominfo) made a statement and denied it by saying that there are no studies that prove the efficacy of onions to prevent the spread of the virus. 
Table 1: The Interesting news by respondents

\begin{tabular}{lcc}
\hline \multicolumn{1}{c}{ Item } & Mean & Std Deviation \\
\hline $\begin{array}{l}\text { Case data of patients Covid-19 in } \\
\text { Indonesia (Number of Positive Cases, }\end{array}$ & 8,21 & \\
$\begin{array}{l}\text { Number of Deaths, Number of Patients } \\
\text { Cured) }\end{array}$ & & \\
$\begin{array}{l}\text { Data of Covid-19 area distribution } \\
\text { (Province, City / Regency, District, }\end{array}$ & 6,55 & \\
$\begin{array}{l}\text { Village) } \\
\text { Information on government rules and } \\
\text { policies for the prevention of Covid-19 } \\
\text { virus }\end{array}$ & 5,53 & 3,20 \\
$\begin{array}{l}\text { Impact of policy implementation (Social } \\
\text { Distancing, Work From Home and } \\
\text { PSBB) }\end{array}$ & 4,97 & \\
$\begin{array}{l}\text { Cases of disobedience (prohibition of } \\
\text { gathering, worship in congregation, } \\
\text { prohibition of going home in holy day) } \\
\begin{array}{l}\text { Memes, funny videos and jokes related } \\
\text { to the Covid virus 19 }\end{array}\end{array}$ \\
$\begin{array}{l}\text { News on how to cure the Covid-19 virus } \\
\text { pandemic }\end{array}$
\end{tabular}

Source: Obtained from Primary Data to WhatsApp Groups User by Online Questioner (2020)

Another form of labeling carried out in the framework of obtaining public trust, namely by including the name of an institution or familiar enough institution in the public that has the capability to deliver information related to COVID-9 pandemic. The aim is to show other users that this information has gone through a scientific testing process at these institutions, so once again no deeper knowledge is needed about the truth of the information.

\section{Robustness and Opportunity}

During the beginning spread of COVID-19 pandemic, messagesshared throughtheWhatsApp group included not only the background of the causes and efforts to prevent the pandemic in terms of the medical field, but also messages that contained the news that this pandemic was the result of a scenario, both designed by humans, to those that have been destined by God.

Beliefs based on religious values generally will illustrate that all the calamities occurred in this world are the result of God's dispatch which is currently giving a test to His servants. This assumption is generally sourced from someone who seeks to provide the explanation to others about the emergence cause of disaster on the basis of belief in the concept of religious teachings. The goal is that everyone can come back to realize the existence of God's power in human life.

Figure 4 were shared by using packaging through referring to primordial beliefs about the concept ofreligious teaching. It shows the strong conviction of a group of people who believes that COVID-19 is solely the creation of Allah Swt., which aims to test the faith of community when there is an appeal for a ban on congregational prayers in the mosque and if one day they die in the mosque because of contracting the virus, then this is considered a death that husnul khotimah (Darmawan, Miharja, Waluyajati, \& Isnaeniah, 2020).

Although the messages shared above have been clarified as a message that can be misleading and impressed as violation form of government appeals regarding temporary restrictions on 
Table 2: The news assesment by respondents

\begin{tabular}{lcc}
\hline \multicolumn{1}{c}{ Item } & Mean & Std Deviation \\
\hline All news are hoaxes & 5,69 & 3,26 \\
Almost the all news are hoaxes & 5,44 & 3,09 \\
$\begin{array}{l}\text { Half of the news are facts and half of } \\
\text { them are hoaxes }\end{array}$ & 6,15 & 4,63 \\
Almost the all news are facts & 3,82 & 2,01 \\
All news are facts & 5,95 & 3,43 \\
\hline
\end{tabular}

Source: Obtained from Primary Data to WhatsApp Groups User by Online Questioner (2020)

religious activities in worship places in an effort to prevent the spread of the COVID-19 (Darmawan et al., 2020) and the occurrence of disinformation related to ablution activities that can destroy COVID-19 (Kominfo, 2020), but this messages is still distributed through chain messages in the WhatsApp group because there is already a strong belief that is inherent when the information refers to a theoretical assumption or a primoridal (religious) belief.

In the information gap analysis, it shows that a strong belief indirectly can limit themselves to find alternative information and narrow an opportunity for receipt of information that is more scientific. In fact, a strong belief should be supported by knowledge that is more scientific and prioritizes the common interest, not for beliefs that originate from more assumptions and egos of a group. In addition, the attitude of self-disclosure to provide opportunities in selecting messages that can be shared with other users, even though the messages shared above have the aim to give warning that all disasters are part of a scenario of God's destiny.

\section{Decision and Information Value}

The diversity of messages shared through the WhatsApp group which causes the uncertainty of the factual information regarding COVID-19 pandemic case has finally provided an opportunity for users to decide on messages based on interests and standardization of subjective judgments.
Interest that comes from personal desire to know one of the information and standardization of assessments that can show how logical the news is to be used as a reference that is common sense.

A survey was conducted on 119 respondents who were active users of the WhatsApp group that aimed to find out how much interest there was in the news and the level of assessment related to messages containing information about COVID-19 pandemic case in Indonesia.

In table 1, the result of the respondents measured based on their interest in the categories of messages shared in the WhatsApp group. In this data, it is illustrated that the users of the WhatsApp group will ultimately decide to choose some news considered important for them to know.

In this table, information that contains data on cases of the development of the sufferer number and the spread of COVID-19 in Indonesia, is a category of messages that are considered very important to know. This is because the message that informs about the level of the patient and the area of the pandemic spread can be used as a reference to see how far the virus has spread in the population of Indonesia. In addition, information related to the latest policies and regulations set by the government, is the next concern of WhatsApp group users.

Respondents decided to choose news based on attractiveness because of the assumption that this choice was based on their desire to know one information. As stated by one respondent: 
"I am interested in the news that was shared in the WhatsApp group when it came to the case data regarding the development of the number of sufferers and the area of the spread of COVID-19 in Indonesia to find out how many Indonesians were infected with the virus. I am also interested in messages that preach about the latest policies taken by the government in the context of handling this virus in Indonesia"(Nurul Mutmainnah, March 30, 2020.)

The decision to choose news based on an interest in finding out information occurs because of the large number of messages that are shared by including a category of information, but sometimes it has the differences in terms of the facts truth. Thus, to minimize the emergence of moral panic over the biased information obtained in these messages, it is necessary to make news choices based solely on the level of interest. In addition, the value of information based on personal assumptions when identifying the truth of a news fact, also becomes an alternative in deciding confidence in an information. One way is done, by identifying hoax news.

In table 2, the level of respondents' assessment comes from how much the public's ability to identify the truth of a story. The identification resultsof these respondents indicate that in general they believe that the comparison between true and hoax news related to reporting COVID-19 cases distributed in the WhatsApp group is in a balanced position. This answer has concluded that there has been information gap that respondents prefer a balanced answer. Not only that, even at the next percentage level, WhatsApp users are more inclined to believe that almost all of the information is fact.

The decision to vote is based on judgment because of the large number of messages shared and sometimes contradictory, so it is necessary to make personal assumptions made by users to choose which news are considered as facts. Conversely, when they assume that the news is hoax, then they decide not to believe it. As stated by a response:
"Sometimes, I find it hard to differentiate between factual and hoax news because of the manymessages thataresharedintheWhatsApp group are conflicting. So, I trust more news that is right" (Haedar, March 30, 2020). Information gaps in reporting on COVID-19 case occur if the WhatsApp group users ultimately tend to be required to make a decision in choosing messages based on their interest and prioritizing personal judgments.

Research by Cinelli et al., (2020), focused on the social media platforms Twitter, Instagram, YouTube, Reddit, and Gab, while this research focused on user of WhatsApp groups. GonzálezPadilla \& Tortolero-Blanco's research, (2020) about the effects, advantages, and disadvantages of using social networks during the COVID-19 pandemic, while for this research on the impact of information on social media in the early spread of Covid-19. Apuke \& Omar's research, (2020) about the phenomenon of spreading fake news on social media related to Covid-19 in Nigeria, this research discusses the spread of fake news related to COVID-19 in Indonesia. Abdullah's, (2020) discusses four types of psychological trauma that occurred in Indonesia as the impact of COVID-19 news on social media, while this research discusses the level of public trust and actions taken in responding the information on social media.

Information about COVID-19 is obtained and disseminated in the WhatsApp group in Indonesia, generally it is not through a process of validating the truth of the facts. There are several gaps in knowledge in responding to news, gaps in opportunities to correct information and gaps in the decision to choose information. Freedom is obtained on WhatsApp, which is the cause of continuous information gaps during the pandemic.

\section{Conclusion}

Information gaps occurred on WhatsApp in early news of COVID-19 in Indonesia is caused by the messages that shared contain things that refer to information gaps in uncertainty, robustness and opportunity to choose 
information and the decision to choose the value of information is determined by WhatsApp users.

First, information gaps of uncertainty in the WhatsApp groups is when a message ignores the fact validation process simply because the information contains actual messages related to the COVID-19 case in Indonesia. In addition, the belief that the information conveyed by including the names of community leaders, experts or institutions is valid.

Second, robustness and opportunity to choose information about COVID-19 are disseminated through the WhatsApp groups, generally originating from the assumptions and ego of a group without being supported by scientific analysis of a message, this has closed the opportunity to choose messages that can be shared with other users.

Third, the decision of information value of COVID-19 based on interest and identification of the correct value of information can occur if more messages are received in the WhatsApp groups, but it actually causes information distortion between one message and another. The decision to choose and tend to prioritize the evaluation of information are based on the results of personal assumptions.

The result of this research ultimately provides an overview of the information gap causes through several sample messages shared by WhatsApp groups users about the development of COVID-19 pandemic case occurred in Indonesia. The occurrence of this information gaps indirectly has also led to increase public panic and lower levels of public trust in messages shared by the WhatsApp groups about the spread of COVID-19 in Indonesia.

The writers hope the results of this research can be continuously developed in the future and it can give contribution about the importance of understanding digital social media for the users, especially for those who relate to the information exchange proces.

\section{References}

Abdullah, I. (2020). COVID-19: Threat and Fear in Indonesia. Psychological Trauma: Theory, Research, Practice, and Policy, 12(5), 488. https://doi.org/10.1037/tra0000878

Anwar, F. (2017). Perubahan dan Permasalahan Media Sosial. Jurnal Muara Ilmu Sosial, Humaniora, Dan Seni, 1(1), 137. https:// doi.org/10.24912/jmishumsen.v1i1.343

Apuke, O. D., \& Omar, B. (2020). Fake news and COVID-19: modelling the predictors of fake news sharing among social media users. Telematics and Informatics, 56, 101475. https://doi.org/10.1016/j.tele.2020.101475

Astarilla, L., \& Warman, D. (2017). The Effect of Whats App in Blended Learning on English as Foreign Language (EFL) Undergraduate Students' Reading Comprehension. In Fifth International Seminar on English Language and Teaching (ISELT 2017). Atlantis Press. https://doi.org/10.2991/iselt-17.2017.14

Ben-Haim,Y.(2004). Uncertainty, probability and information-gaps. Reliability Engineering and System Safety, 85(1-3), 249-266. https://doi.org/10.1016/j.ress.2004.03.015

Bungin, \& Burhan. (2009). Sosiologi Komunikasi: Teori, Paradigma, dan Diskursus Teknologi Komunikasi di Masyarakat. Kencana Prenada Media Group. Cheng, Y., Luo, R., Wang, K., Zhang, M., Wang, Z., Dong, L., ... Xu, G. (2020). Kidney impairment is associated with in-hospital death of COVID-19 patients. MedRxiv. https:// doi.org/10.1101/2020.02.18.20023242 Cinelli, M., Quattrociocchi, W., Galeazzi, A., Valensise, C. M., Brugnoli, E., Schmidt, A. L., ... Scala, A. (2020). The COVID-19 social media infodemic. Scientific Reports, 10(1). https://doi. org/ $10.1038 / \mathrm{s} 41598-020-73510-5$ Cohen, S. (2011). Folk devils and moral panics: The creation of the Mods and Rockers. In Folk Devils and Moral Panics: The Creation of the Mods and Rockers. https://doi.org/10.4324/9780203828250 
Darmawan, D., Miharja, D., Waluyajati, R. S. R., \& Isnaeniah, E. (2020). Sikap Keberagamaan Masyarakat Menghadapi Wabah COVID-19. Religious: Jurnal Studi Agama-Agama Dan Lintas Budaya, 4(2), 115-124. https://doi.org/10.15575/rjsalb.v4i2.8596

González-Padilla, D. A., \& TortoleroBlanco, L. (2020, July 1). Social media influence in the COVID-19 pandemic. International Braz J Urol, 46, 120-124. Brazilian Society of Urology. https:/doi. org/10.1590/S1677-5538.IBJU.2020.S121

Juditha, C. (2018). Hoax Communication Interactivity in Social Media and Anticipation (Interaksi Komunikasi Hoax di Media Sosial serta Antisipasinya). Journal Pekommas, 3(1), 31. https:// doi.org/10.30818/jpkm.2018.2030104

Kaplan, A., \& Mazurek, G. (2018). Social media. In Handbook of Media Management and Economics: Second Edition (pp. 273-286). Taylor and Francis. https:// doi.org/10.4324/9781315189918

Kominfo. [DISINFORMASI] Wudhu Bisa Hancurkan Virus Corona, 02 Februari 2020, <https://kominfo.go.id/content/ detail/24134/disinformasi-wudhu-bisahancurkan-virus-corona/0/laporan isu_hoaks $>$ [accesed, 19 March 2020]

Kominfo. [HOAKS] Penyembuhan Virus Corona dengan Bawang Putih, 28 Januari 2020,. <https://kominfo.go.id/content/ detail/24029/hoaks-penyembuhan-viruscorona-dengan-bawang-putih/0/laporan isu hoaks $>$ [accesed, 19 March 2020]

Lai, C.-C., Shih, T.-P., Ko, W.-C., Tang, H.-J., \& Hsueh, P.-R. (2020). Ards
COVID19. International Journal of Antimicrobial Agents, 7 . https://doi. org/10.1016/j.ijantimicag.2020.105924

Mahmuddin, \& Halik, A. (2019). The use of social media as a source of religious knowledge among doctors in Makassar, Indonesia. Jurnal Komunikasi: Malaysian Journal of Communication, 35(4), 272-285. https:// doi.org/10.17576/JKMJC-2019-3504-17 Rahadi, D. R. (2017). Perilaku Pengguna Dan Informasi Hoax Di Media Sosial. Jurnal Manajemen dan Kewirausahaan, 5(1), 5870. https://doi.org/10.26905/jmdk.v5i1.1342 Rochmyaningsih, D. (2020). Indonesia finally reports two coronavirus cases. Scientists worry it has many more. Science, 1. https://doi.org/10.1126/science.abb5653

Update Covid-19, Kasus Baru Bertambah 114 Orang, 31 March 2020. $<$ https://databoks.katadata.co.id/ datapublish/2020/03/31/update-covid19-kasus-baru-bertambah-114-orangselasa-313> [accesed, 4 April 2020] Verity, R., Okell, L. C., Dorigatti, I., Winskill, P., Whittaker, C., Imai, N., ... Ferguson, N. (2020). Estimates of the severity of COVID-19 disease. MedRxiv, 2020.03.09.20033357. https:// doi.org/10.1101/2020.03.09.20033357

WHO Coronavirus Disease COVID-19. (January 21 - February 20, 2020). <https:// covid19.who.int/ $>$ [accesed, 2 April 2020]

Worldometer, Coronavirus Cases Report, 31 March 2020, <https://www. worldometers.info/coronavirus / coronavirus-cases/ $>$ [accesed, 2 April 2020]

Yunita, N. (2020). Penyebab, Asal Mula, dan Pencegahan Virus Corona di Indonesia. Detik. 